\title{
Dimensions of Main Character in Victor Hugo's Les Miserables
}

\author{
Ni Nyoman Kertiasih ${ }^{1}$, Andreas Julison Nainggolan ${ }^{2}$ \\ $\left\{\right.$ kertiasing@gmail.com ${ }^{1}$, julison.nainggolan@gmail.com ${ }^{2}$ \} \\ 1,2Universitas Warmadewa Denpasar-Bali, Indonesia
}

\begin{abstract}
The aim of the study that can be reached was the kinds of dimensions of the main character. The study focused on analyzing and discussing about the dimensions of the main character of the novel created by Victor Hugo, Les Miserables. The data source of this study was taken from a new simplified edition novel published online in 2015 by E-Pen Book Publisher Company, Inc. on their own site, which the original version was written by a very famous author, Victor Hugo, entitled Les Miserables. Then the data are analyzed based on the theory of character. In analyzing the dimensions of the main character, the researcher applied the theory of LajosEgri. The analysis were done descriptively, which means that the novel were analyzed by giving some comments on it supported by the examples sentences mentioned in the novel. Based on the result of the analysis, it can be concluded that there are three kinds of dimensions found in Hugp'sLes Miserables, they are Physiological Dimension, Psychological Dimension and Sociological Dimension. The physiological part of the dimensions relates to the physics of the character in the story. The psychological dimension relates to the attitude and the behavior of the main character, while, the sociological dimension can be seen through the main character's social class.
\end{abstract}

Keywords-Main Character, physiological, sociological

\section{Introduction}

A work of fiction is a branch of literature. In modern period, however the story of the fiction uses more the human beings as its character than the non-human being ${ }^{[1]}$. In the human civilization, literature has been accepted as one of social cultural realities, and is not just regarded as an art work concerning with mind, emotion, and imagination, but also as a creative work using language as its medium. Its existence in the human civilization actually imitates life, and life is in larger measure, a social reality, even though the natural world and the inner or subjective world of the individual have also been objects of literary imitation.

Literary works contain of intrinsic elements and extrinsic elements. The intrinsic elements are internal elements which build the structure of literary work. Those intrinsic elements are theme, plot, setting, character and characterization, and conflict. On the other hand, the extrinsic elements are those which are outside of the related to literary works following to build 
the structure of the literary works. The extrinsic elements are autobiography, politics, and history of the author.

Literary works have three kinds of form, such as novel, poetry, and drama. In this study, novel is chosen as the data source. Novel is one of literary works. Novel contains of ideas and imaginations of the author inspired by the reflection of human life experience. The elements of the novel are intrinsic and extrinsic elements. Intrinsic elements of novel are theme, character, setting, point of view, style, and mandate. Character is one of the intrinsic elements that has an important role to build up the intrinsic structure of the novel.

Character or habits show how an individual is going to act under some certain conditions. Character is constantly affecting how people think and act. According to the function, character can be categorized into three kinds, they are main, supporting, and complementary character ${ }^{[2]}$. In the sense of reality, character has life dimensions which structured of physiological, psychological and sociological dimension ${ }^{[3]}$.

Some latest related studies have been carried out to differentiate this present study with those studies, one of the related studies was study about the three dimensional aspects of the major character in Oscar Wilde's Vera. The study discussed the dimensions of Vera as the major character there. As the major character, Vera is described into three dimensional namely physiological, Psychological, and Sociological. Physiologically, Vera is described as a beautiful young lady with beautiful eyes. Sociologically, Vera is concluded as coming from an average family in Russia, living in a poor society, and living under tyranny. She has lived in an inn with her father before she saw her brother taken away to prison for seeking for liberty as a Nihilist. Psychologically, Vera is seen as a loving person though she does not put love as priority. She loves her country and her brother. She wants to revenge on the King for being a tyrant. She is a brave woman. It is seen from how she becomes a Nihilist to revenge for her brother and to end up the tyranny in her country ${ }^{[4]}$. The further related study was about the main and secondary characters in 47 Ronin movie in terms of method of characterization. The main issue that differentiate this third related study with this present study. On that study, researcher tried to describe the main and secondary character based on the three dimensional while the three dimensional of this present study was described on the main character only ${ }^{[5]}$.

The complexity of the dimensions of the main character in Les Miserables by Victor Hugo is really interested to be analyzed. There was problem needed to be analyzed, that is what kinds of dimensions of the main character and also their characterizations are narrated in the story? Therefore, the aim of the study that can be reached was the kinds of dimensions of the main character.

\section{Methods}

The data source of this research is the novel entitled Les Miserables by Victor Hugo. This first step of data collection was done by reading them. The data was collected by reading the whole references and then taking a note on what are related to the problems that were going to be analyzed in this study. Then, all the collected data were further analyzed based on the theoretical concept. The analysis were done descriptively, which means that the novel were analyzed by giving some comments on it supported by the examples sentences mentioned in the novel. 


\section{Result and Discussion}

There are three dimensions of the main character found in the novel, they are Physiological Dimension, Psychological Dimension, and Sociological Dimension.

\subsection{Physiological Dimension of the Main Character and Its Characterizations}

Physiological aspect of a character is observed through age, sex, body-shape, skin and hair color. The characterization of the Physiological Dimension of the main character is found as following.

"One evening in October 1815, an hour before sunset, a man with a long beard and dusty, torn clothes walked into the town of Digne. He was in his late forties, of medium height, broadshouldered and strong" (Hugo, 2015: 1)

From the data above, it can be concluded that Jean Valjean was a male, since the author uses the word 'man' to describe the gender of the person. Besides, he also uses nominative pronoun "he" to describe the main character.

"Then, seeing the visitors rough appearance, he added, 'If you can pay for it."' (Hugo, 2015: 1)

So, this is Jean Valjean who had never been seen on the town for 19 years, now walking towards the town as a freeman (though its temporarily free, but it's good to take a fresh breath for a while). He entered an inn and asked the innkeeper for a meal to eat and a bed to stay. The innkeeper who was busy with his pots and pans, suddenly answered 'of course', without turning his body to Jean Valjean. But, when he finally turned his body to Valjean and seeing Valjean's rough appearance, the innkeeper quickly added, 'if you can pay for it'. He said that, because of the 'beggar-looks' of Valjean.

"M. Madeleine had arrived mysteriously in Montreuil one December evening in 1815." (Hugo, 2015: 14)

By the end of December, Valjean had a journey to Montreuil town and changed his identity.

"The reader has probably already realized that M. Madeleine was really Jean Valjean, and M. Madeleine - as we shall continue to call him for this part of the story." (Hugo, 2015: 18)

On December 1815, Jean Valjean had totally changed his identity into Monseigneur French word for 'My Lord'- Madeleine as shown in the quotation above.

"The next morning, M. Madeleine set off on the long journey to Arras." (Hugo, 2015: 18) After Valjean went back to look after Cosette, Javert came and arrested him. "Then he rose and turned back to Javert. 'I'm ready now,' he said." (Hugo, 2015: 20)

Apparently, based on what is quoted above, Jean Valjean had been arrested because he had revealed his own identity to the court where the court was sueing another man who they were thought to be Jean Valjean. Because of this, Inspector Javert, the police officer who were the ex-prison guard of Jean Valjean had him arrested. But, after two days in the prison, Valjean escaped.

"Christmas 1823 was especially lively and colourful in the village of Montfermeil. Entertainers and traders from Paris set up their stalls in the streets, and business at the Thenardiers' inn was very good. While guests and visitors ate and drank noisily, Cosette - now eight years old - sat in her usual place under the kitchen table. Dressed in rags, she knitted woollen stockings for Eponine and Azelma..." (Hugo, 2015: 22)

It is explained in data above that 2 years (1823) after Jean Valjean escaped from the local small town prison of Montreuil city in 1821, he went to a village called Montfermeil to pick Cossete up as what he promised to Fantine, Cossete's mother, before she died, that he would take care of her daughter. 


\subsection{Psychological Dimension of the Main Character and Its Characterizations}

Psychological dimension of a character is the characteristic of his behavior, emotion and thought.

"The innkeeper approached and, bending towards the man, said in a fierce whisper, 'Get out. I know who you are. Your name is Jean Valjean. You've just been released from prison. I can't serve people like you here.' The man rose without another word, picked up his bag and stick, and left." (Hugo, 2015: 2)

At this time, Jean Valjean had just been released on parole after being sentenced on prison for 19 years under the consequences of his committed crime that was stealing a loaf of bread, which he actually did to feed her sick sister. When he got out of the prison, he searched for an inn to stay, and when he found one, what is written in the first data above happened.

"Outside, it was growing dark and a cold wind was blowing from the mountains in the east. The man looked around, desperate for somewhere to spend the night. He tried another inn, but the same thing happened. He knocked on the doors of people's houses, but news of his arrival had quickly spread and nobody would offer him shelter from the cold. He even tried sleeping in a garden, but was chased away by a dog. Finally, he found himself in the cathedral square. He shook his fist at the church and then, cold and hungry, he lay down on a stone bench by the doorway" (Hugo, 2015: 2)

It is written in the data above that the main character tried from one to another and to another inn, but the same thing happened. He even tried sleeping in the garden of someone's house, but was chased away but the owner's dog. Then, he found a cathedral square, and slept on a stone bench by the doorway. What a life. It was tough. But, he didn't give up till he got what he needed.

"A few minutes later, an old woman came out of the cathedral and saw him lying there.

'What are you doing?' she asked.

He answered angrily, 'Can't you see? I'm trying to sleep.'

'On this bench, in this cold wind?'

'I've slept for nineteen years on a piece of wood. Now it's stone. What's the difference?'” (Hugo, 2015: 2)

In the explanation of data above, what the writer of this paper trying to tell was that Valjean wasn't a man who easily got angry or taking everything in a violence way, but it does not necessarily mean that he couldn't be angry. A patience man, if being forced to his limit, surely will be get angry. Therefore, it is understandable if in this situation Valjean got angry. Because, he had searched for a place to stay all night long, and had been cast out over and over even ever he been cast out by a dog.

“...Valjean took a step forward. 'No, you don't understand,' he said. 'I've spent five years in prison for violent robbery, another fourteen years for trying to escape four times. I'm a dangerous man.' (Hugo, 2015: 3)

That paragraph of page 3 gives us a firm confirmation that Valjean knew that himself was a dangerous man.

"The policemen left, but Valjean did not move. He did not know what to think. The bishop walked up to him and said in a low voice, 'Don't forget that you've promised to use the money to make yourself an honest man.' Valjean, who did not remember having made such a promise, was silent. 'Jean Valjean,' the bishop continued, 'I've bought your soul from the Devil, and have given it to God."' (Hugo, 2015: 6)

The bishop's way of showing mercy to Valjean, by telling the policeman that Valjean was not a thief, but was a man who the bishop knew. The candlesticks which Valjean actually really stole, the bishop told the policemen that it was given by the bishop. Evidently, that made 
Valjean confused. He couldn't believe what was happening to him. After the policemen left, what was 'beyond-mind' taking place.

"Now, years later, M. Madeleine was in the police station, trying to save Fantine from prison. Fantine, however, was not grateful. In fact, when she saw who it was, she spat at him.

'You own the factory where I used to work!' she shouted at him. 'I lost my job because of you. Now I've become a bad woman, but what choice did I have? I'll never get my daughter back if I don't make money."' (Hugo, 2015: 15)

Fantine who was an ex-employee of one of M. Madeleine's factory, now got arrested by Chief Police, Inspector Javert, accused of beating up a man. Shortly, it all happened because of Fantine got fired from her job at a factory owned by M. Madeleine.

\subsection{Sociological Dimension of the Main Character and Its Characterization}

Sociological Dimension of the main character is analyzed through several aspects, which are the social life of the character, house, job, education and the social status.

The first chapter shows us 'a poor Valjean' which just got out from prison on parole, shown on data below.

"One evening in October 1815, an hour before sunset, a man with a long beard and dusty, torn clothes walked into the town of Digne. He was in his late forties, of medium height, broadshouldered and strong. A leather cap half-hid his face, which was sunburnt and shining with sweat. His rough yellow shirt was unbuttoned, revealing a hairy chest. On his back was a heavy soldier's bag, and in his hand was a large wooden stick." (Hugo, 2015: 1)

Through his psychological appearance, the writer can take a conclusion on his social status. With no doubt, it can be concluded he was a poor man.

'“'What can I do for you, Monsieur?' he asked without looking up.

'A meal and a bed,' said the stranger.

'Of course.' The innkeeper turned to look at him. Then, seeing the visitors rough appearance, he added, 'If you can pay for it."' (Hugo, 2015: 1)

After seeing Jean Valjean's rough appearance, the innkeeper suddenly said 'if you can pay for it' (Hugo, 2015: 1). It means he saw Jean Valjean as a poor man. Inside the innkeeper's perspective on Jean Valjean, Jean Valjean's social status was a poor guy.

"The door opened and Jean Valjean, the stranger, walked in. Mme Magloire trembled, open-mouthed with fear, while Mile Baptistine rose from her seat with alarm. The bishop, however, looked calmly at his unexpected visitor.

'My name is Jean Valjean,' the stranger said before anybody could speak. 'I've been in prison for nineteen years. They let me out four days ago. I've been walking all day, and nobody in this town will give me food or a bed for the night. A woman saw me lying on a stone bench across the square and suggested that I come here. So here I am. What is this place? Is it an inn? I've got money. Will you let me stay?'...” (Hugo, 2015: 3)

Apparently, the bishop looked Jean Valjean differently. Even though, Jean Valjean had told the bishop everything about his background, but the bishop looked him just the way he looked at others. Because of this, Jean Valjean repented and all of a sudden in a couple of months he changed into a completely better person and changed his identity into M. Madeleine.

"M. Madeleine had arrived mysteriously in Montreuil one December evening in 1815 . He had no money but he had a revolutionary idea: he knew a cheap and efficient method of manufacturing glass. Within a few months of his arrival, thanks to his new idea, the glassmaking factory in Montreuil was making enormous profits. With the money he made, M. Madeleine built two new factories, which provided the town with hundreds of new jobs. He became a very wealthy man but lived a simple life, using most of his money to build new 
hospitals and schools. He was so popular that, in 1820, the townspeople elected him mayor of Montreuil." (Hugo, 2015: 14)

At the end of 1815 till 1820, M. Madeleine, which is Jean Valjean became a wealthy dignified man. Because people of the town knew him as a wealthy man who provided hundreds of new jobs with his factories and also built up new hospitals and schools, so in 1820, the Montreuil people elected him as the mayor of the town. His financial and social condition here was on top.

But, not long after its high social status, a tragedy happened which forced him to admit that he was the past criminal, Jean Valjean, who ran from the parole. The tragedy explained below by the following quotation.

"'The police headquarters in Paris told me that Jean Valjean was arrested last autumn for stealing apples,' Javert explained. He'd changed his name to Champmathieu and had lived for several years in the village of Ailly-le-Haut-Cloche. Two ex-prisoners from Toulon recognized him as Jean Valjean. I visited the man in Arras prison, and I saw for myself that he is indeed Jean Valjean. Of course, he denies everything, but that's not surprising. If he's found guilty of stealing from the bishop - who, as you know, died a couple of years ago - and of robbing the small boy, he'll spend the rest of his life in prison."' (Hugo, 2015: 16)

2 years, after searching out for Cosette, finally he found the city where Thenardier's inn the place Cosette lived with the Thenardiers- was located. When Jean Valjean arrived at Thenardier's inn, he wanted to rent a room. But, Mme Thenardier said the room was full, because she saw Valjean wore a rag clothes.

"'This gentleman wants a room for the night,' Cosette said, trembling with fear, expecting to be beaten.

Mme Thenardier glanced at the old man without interest. She could tell from his clothes that he probably had no money.

'I'm sorry, the rooms are full,' she said." (Hugo, 2015: 23)

But, Valjean replied that he could pay.

"'I can pay the price of a room,' the old man said.

'Forty sous,' Mme Thenardier replied (although the usual price was twenty). 'Forty sous,' the man agreed." (Hugo, 2015: 23)

Even, Valjean agreed to the 'un-normal' price. He was a business man, he often went for business trip, he must had known the price of a normal inn with any model or any type. However, he was agreed to the price. It means here that Jean Valjean was still rich, proven by how easy he agreed to the room payment.

"The Thenardiers gave the old man their best room for the night. The next morning they gave him the bill, charging him three times the usual price for a meal and a bed for the night. They waited nervously while the man studied the bill carefully, expecting him to complain or cause trouble. Finally, he looked up from the bill without expression and said, 'Tell me, is business good here in Montfermeil?"' (Hugo, 2015: 25)

Data above gave us a solid information that Jean Valjean bought the most expensive doll in town for Cossete. His wealth was like an endless pit. This confirmed that he was still rich here 


\section{Conclusion}

There are three dimensions of the main character found in the novel, which are Physiological Dimension, Psychological Dimension, and Sociological Dimension. The physiological aspect of a character is observed through age, sex, body-shape, skin and hair color, where the psychological dimension is analyzed through the behavior, thought, and emotion of the character. The sociological dimension deals with the social life of the character. It can be seen through the condition of the house, the character's job, wealth, education and social status.

\section{References}

[1] C. R. Reaske, How to Analyze Drama. New York: Monarch Press, 1970.

[2] M. Sukada, Pembinaan Kritik Sastra Indonesia. Bandung: Angkasa, 1987.

[3] L. Egri, The Art of Dramatic Writing. New York: Simon and Schuster, 1946.

[4] I. wayan Mulyawan, "Three Dimensional Aspects of the Major Character in Oscar Wilde's Vera," English Department Udayana University, vol. 15, no. 1, 2015.

[5] K. A. Wirawan, "Analysis of Main and Secondary Characters in 47 Ronin Movie in Terms of Method of Characterization and Three Dimensions of Characters," E-Jurnal Humanins Fakultas Sastra dan Budaya Unud, vol. 15, 2016. 